\title{
Dampak Sampah Plastik Terhadap Kesehatan dan Lingkungan
}

\author{
Else Auvi Dalilah \\ Iik Strada Indonesia \\ elseauvi0@gmail.com
}

\begin{abstract}
Abstrak
Plastik adalah benda yang sering kita temui dalam kehidupan sehari hari, dikemas dalam bentuk yang berbeda sesuai dengan fungsinya masing masing. Plastik memberikan banyak manfaat untuk masyarakat, penggunaan plastik yang praktis dan aman untuk menyimpan dan membawa barang menjadi pilihan masyarakat modern. Dengan bahan yang ringan dan ideal untuk berbagai macam peralatan yang dibutuhkan seperti peralatan rumah tangga dan peralatan lainya, dalam aspek kehidupan plastik memberikan alternatif pilihan yang lebih efisien dari bahan lainya. Keberadaan plastik memang tidak bisa jauh dari aktivitas manusia, hampir setiap kegiatan manusia menggunakan plastik. Semakin hari sampah plastik mengalami kenaikan seiring dengan tingginya konsumsi masyarakat terhadap penggunaan plastik, seperti meningkatnya produk plastik sekali pakai tetapi tidak diimbangi dengan penanganan limbah plastik. Selain memiliki segudang manfaat plastik merupakan salah satu penyebab pencemaran lingkungan. Plastik memiliki waktu daur ulang yang lebih lama dari bahan lainya bahkan ada yang tidak dapat didaur ulang seperti styrofoam.

Kehadiran sampah plastik memiliki banyak ancaman bagi lingkungan dan kesehatan. Sebagai masyarakat kita mempunyai kewajiban untuk mengurangi penggunaan sampah plastik, dapat dilakukan dari hal kecil seperti mengganti kantong plastik sekali pakai dengan kantong ramah lingkungan.
\end{abstract}

\section{Latar belakang}

Plastik adalah benda yang sering kita temui dalam kehidupan sehari hari, dikemas dalam bentuk yang berbeda sesuai dengan fungsinya masing masing. Dengan bahan yang ringan dan ideal untuk berbagai macam peralatan yang dibutuhkan seperti peralatan rumah tangga contohnya seperti botol minum, wadah makanan, piring, gelas dan peralatan masak lainya. Dalam aspek kehidupan plastik memberikan alternatif pilihan yang lebih efektif dan efisien dari bahan lainya, dengan bahan yang lebih mudah dibetuk dan ringan. Keberadaan plastik memang tidak bisa jauh dari aktivitas manusia, hampir setiap kegiatan manusia menggunakan plastik, contohnya seperti membungkus makanan dengan menggunakan styrofoam dan kantong plastik, minuman dikemas dengan menggunakan wadah sekali pakai dan sedotan sekali pakai, kantong bungkus belanjaan sebagian masih menggunakan plastik sekali pakai. Dipasar tradisonal di daerah Banyuwangi tepatnya di Kecamatan Genteng pedagang masih menggunakan plastik sekali pakai sebagai bungkus belanjaan.

Semakin hari sampah plastik mengalami kenaikan seiring dengan tingginya konsumsi masyarakat terhadap penggunaan plastik, seperti meningkatnya produk plastik sekali pakai tetapi tidak diimbangi dengan penanganan limbah plastik. Selain memiliki segudang manfaat plastik merupakan salah satu penyebab pencemaran lingkungan. Plastik memiliki waktu daur 
ulang yang lebih lama dari bahan lainya bahkan ada yang tidak dapat didaur ulang seperti styrofoam. Kehadiran sampah plastik memiliki banyak ancaman bagi lingkungan dan kesehatan. Dampak sampah plastik bagi lingkungan, bahan plastik membutuhkan waktu yang cukup lama bahkan sampai bertahun tahun untuk bisa terurai, selain itu plastik juga mengandung zat beracun, bila sampah plastik ditimbun di tanah makan akan menyebabkan kerusakan pada tanah, jika sampah plastik dibakar akan menyebabkan polusi udara dan mengeluarkan zat beracun ke udara yang dapat dihirup oleh manusia. Selain berbahaya untuk manusia limbah sampah juga menimbulkan bahaya bagi hewan.

Selain manusia hewan juga terkena dampak limbah plastik, banyak hewan-hewan yang mengonsumsi sampah plastik karena mereka bingung membedakan sampah plastik yang menyeruapi makanan mereka. Hal tersebut sangat bahaya jika dilakukan terus menerus karena dapat menyebabkan masalah pencernaan pada hewan dan juga menyebabkan kematian hewan. Selain kesehatan dan lingkungan sampah plastik juga berdampak bagi pertanian, sampah plastik yang dibuang di lahan pertanian tentu dapat menyebabkan pencemaran di daerah pertanian.

Sampah plastik juga dapat menyebabkan bencana alam seperti banjir, jika kita membuang sampah sembarang seperti disungai dan diselokan, saat terjadi hujan lebat sampah tersebut menyumbat saluran air sehingga air tidak dapat mengalir menyebabkan air meluap dan menyebabkan banjir, selain itu sampah juga menyebabkan pencemaran air, sungai dan laut menjadi kotor karena banyak sampah plastik menggenang. Kurangnya kesadaran masyarakat membuang sampah ditempat sampah menyebabkan kerusakan alam.

\section{Kasus atau Masalah}

Masalah sampah di Indonesia menjadi salah satu masalah besar, menurut data SIPSN atau Sistem Informasi Pengelolaan Sampah Nasional, capaian kinerja pengelolaan sampah dan penanganan sampah rumah tangga dan sampah sejenis sampah rumah tangga pada tahun 2020 yang terdiri dari 275 Kabupaten/kota se-Indonesia.

1. Timbulan sampah

2. Pengurangan sampah

3. Penanganan sampah

4. Sampah terkelola

5. Sampah tidak terkelola
: 33,113,277.69 (ton/tahun)

: 4,461,873.02 (ton/tahun) $13.47 \%$

: $15,169,743.06$ (ton/tahun)

: 19,631,616.08 (ton/tahun) 59.29\%

$: 13,481,661.61$ (ton/tahun) $40.71 \%$

Indonesia menjadi negara dengan penghasil sampah terbanyak no 2 di dunia, sampah plastik sebanyak 1,3 ton berasal dari laut dan sungai. Penyebab banyaknyasampah di Indonesia, yaitu :

1. Kurangnya kesadara masyarakat membuang sampah pada tempatnya, masih banyak warga yang membuang sampah disungai dan selokan

2. Kurangnya solusi yang diberikan oleh pemerintah, semakin berkembangnya teknologi pemerintah seharusnya menyediakan teknologi yang dapat mendaur ulang sampah dengan efektif dan efisien

3. Masyarakat lebih memilih menggunakan kantong plastik sekali pakai, daripada menggunakan kantong atau wadah ramah lingkungan

4. Gaya hidup konsumtif menyebabkan masyarkat memilih menggunakan barang yang praktis dan mudah digunakan 
Jenis-jenis plastik dan bahayanya :

1. PET : Jenis plastik ini hanya satu kali pemakaian, jika terlalu sering digunakan apalagi untuk menyimpan air panas lapisan polimer akan meleleh dan mengeluarkan zat karsinogenik penyebab kanker

2. HDPE : Bahan platik aman, sifat bahan keras, kuat, dan tahan suhu tinggi. Walaupun cukup aman tetapi jangan sering menggunakan wada berbahan ini

3. PVC : Lebih tahan kimia, bahan ini jika bereaksi dengan makanana menyebabkan kerusakan pad ginjal

4. LDPE : Sifat kuat, agak fleksibel, dapat didaur ulang contohnya tempat makan dan botol minum

5. PP : Kuat dan ringan, stabil terhadap suhu

6. PS : Bahan ini mengeluarkan styrene, bahan yang harus dihindari karena berbahaya untuk otak dan mengganggu hormon estrogen berakibat pada repoduksi wanita.

7. OTHER : Bahan ini dianjurkan bukan untuk makanan dan minuman karean mengandung styrene acrylonitrile, acrylonitrile butadiene stryene, polycarbonate, nylon

\section{Tinjauan Pustaka}

Pada zaman dahulu masyarakat belum banyak menggunakan plastik, masih menggunakan bahan organk yang terbuat dari rotan dan bambu, hal itu berbanding terbalik dengan zaman sekarang. Plastik merupakan bahan yang kita temui disetiap barang, hampir semua barang yang kita gunakan berasal dari plastik, dari peralatan rumah tangga sampai industri. Menurut peneliti menggunakan plastik yang tidak sesuai dengan persyaratan dapat menimbulkan gangguan kesehatan, dapat mengakibatkan kanker dan juga kerusakan jaringan pada tubuh mansuisa. Plastik juga sulit diuraikan oleh organisme, sampah [plasyik bisa bertahan hingga bertahun-tahun lamanya dan menyebabkan pencemaraan bagi lingkungan . jika dibakar menyebabkan polusi udara, dan jika ditimbun ditanah dapat menyebabkan pencemaran pada tanah. Plastik memiliki jenis-jenis kode yaitu, PET, HDPE, PS, PP, LSPE, PVC, OTHER, platik yang aman digunakan mempunyai kode LDPE, HDPE, OTHER, PP kecuali pvc. Plastik adalah bahan yang mudah didapat, tahan lama dengan harga yang murah hal itu menyebabkan manusia menjadi ketergantungan dengan plastik, tetapi sayangnya masih banyak masyarkat yang tidak paham bahaya dari plastik dan cara mengunakan plastik yang benar. Sampah plastik menjadi musuh yang serius bagi kelestarian hidup.

Upaya yang dapat dilakukan untuk penanggulangan limbah plastik yaitu :

1. Mengurangi penggunaan plastik dapat menggantinnya dengan kantong ramah lingkungan yang dapat digunakan berkali kali.

2. Penggunaan kembali atau daur ulang, sampah plastik dapat dijadikan kerajinan yang lebih bermanfaat dan memiliki nilai guna yang lebih tinggi

3. Menghindari buang sampah dilingkungan

4. Mengurangi penggunaan barang-barang yang berbahan plastik

Sampah saat ini dianggap sebagai masalah, sampah dianggap sesuatu yang kotor dan harus dibuang, jika dibuang sembarangan dapat menimbulkan pencemaran dan sumber penyakit. Jika dibuang ditempat sampah bukan berarti tidak menimbulkan masalah, karena timbul masalah baru pada pembuangan akhir. Maka pemikiran tentang sampah harus dirubah, 
yang awalnya sampah harus dibuang menjadi sampah harus di daur ulang atau dimanfaatkan kembali.

\section{Pembahasan}

Sampah plastik memang diciptakan untuk membantu kehidupan manusia, tetapi disisi lain memiliki banyak masalah yang bukan hanya merugikan manusia tetapi hewan dan juga alam merakasan imbas dari adanya limbah plastik. Kita juga tidak bisa lepas dari plastik, karena plastik mempunyai fungsi yang efisien dengan haraga yang ramah dikantong, tetapi hal tersebut bukan malah menjadikan kita untuk terus menerus menggunakan plastik, kita harus tetap bijak dalam penggunaan plastik, harus tau juga bahaya dari plastik yang kita gunakaan, jangan karena tergiur dengan kepraktisan dan manfaat yang diberikan menjadikan kita lupa akan sisi lain dari penggunaam plastik. Kesadaran masyarakat penting untuk tetap menjaga kebersihan lingkungan dengan tidak membuang sampah sembarangan, seperti membuang samaph disungai dan dilaut. Sebaiknya plastik yang dapat didaur ulang bisa diubah fungsi menjadi barang barang yang lebih bermanfaat dan berguna.

Kita dapat mengganti kantong plastik sekali pakai dengan kantong ramah lingkungan, mengganti sedotan sekali pakai dengan sedotan bambu atau stainless stell yang dapat digunakan berkali-kali. Membawa kantong belanja dari rumah agar menghemat penggunaan plastik. Kewajiban kita sebagai masyarakat untuk ikut menjaga kesehatan lingkungan dan kesejahteraan alam, agar generasi penerus kita dapat merasakan lingkungan yang sehat, lakukan dari hal-hal kecil seperti tanggung jawab terhadap sampah yang kita punya.

\section{Kesimpulan}

Penggunaan sampah plastik memang tidak bisa jauh dari kehidupan manusia, disatu sisi mendatangkan manfaat yang cukup besar disisi lain memiliki kekurangan yang cukup besar bagi kesehatan dan sulit diurai oleh lingkungan, hal itu menyebabkan plastik dan limbahnya menimbulkan masalah baru bagi lingkungan. Tetapi keberadaan plastik tidak dapat jauh dari manusia, sehingga manusia perlu menimbangkan dalam pemakaian plastik dengan baik dan benar supaya mendapatkan manfaat yang baik tetapi tidak mengakibatkan masalah baru terhadap lingkungan.

Memanfaatkan limbah plastik dengan merubahnya menjadi barang barang yang lebih berguna dan bermanfaat, seperti merubah botol plastik menjadi kursi yang menghasilkan fungsi dan nilai jual yang tinggi, dengan kita memanfaatkan limbah plastik dengan benar kita ikut melestarikan lingungan alam. Kita juga dapat menghasilkan uang dari limbah plastik seperti contoh diatas, tidak semua yang buruk tidak berguna, tapi bagaimana caranya kita dapat memanfaatkan apa yang ada di alam dengan kreativitas yang kita punya. Jangan hanya bisa menghasilkan sampah tapi jadilah anak muda yang bisa merubah sampah menjadi nilai guna.

Menghindari pembuangan sampah sembarangan, jangan karena menuruti ego untuk membuang sampah sembarang sehingga orang lain dan alam merasakan keruskaan karena ulah tangan kita, manffatkan sampah yang bisa digunakan, dan jika memang sampah tesebut tidak bisa digunakan lagi atau didaur ulang maka buang ditempat yang memang untuk pembuangan sampah. 


\section{Daftar Pustaka}

Adi, A. (2005). Dampak Sampah terhadap Kesehatan Lingkungan dan Manusia.7 Oktober 2021 $\underline{(7: 55)}$

N Karuniastuti 2013. Bahaya plastik terhadap kesehatan dan lingkungan.

http://ejurnal.ppsdmmigas.esdm.go.id/sp/index.php/swarapatra/article/view/43 7 Oktober 2021 (8:30)

Merdeka.com 7 April 2021 (16:00) https://www.merdeka.com/jabar/dampak-sampah-plastik-bagilingkungan-dan-ekonomi-begini-cara-menanganinya-kln.html 7 Oktober 2021 (8:51)

https://sipsn.menlhk.go.id/ 7 Oktober 2021 (11:06)

Sodik, M. A., Suprapto, S. I., \& Pangesti, D. (2013). Faktor-Faktor Yang Berhubungan Dengan Pelaksanaan Pelayanan Prima Pegawai Di Rsui Orpeha Tulungagung. STRADA Jurnal IImiah Kesehatan, 2(1), 24-32.

Sodik, M. A., \& Nzilibili, S. M. M. (2017). The Role Of Health Promotion And Family Support With Attitude Of Couples Childbearing Age In Following Family Planning Program In Health. Journal of Global Research in Public Health, 2(2), 82-89.

Attoriq, S., \& Sodik, M. A. (2018). Pencegahan Dan Pengendalian Infeksi Terkait Pelayanan Kesehatan Di Lahan Praktik.

Oktoriani, E. N., Sutrisno, J., Mayasari, E., \& Sodik, M. A. (2018). Analysis of medical record complete flexibility to complete claims of health BPJS RS Baptis Kota Batu. Journal of Global Research in Public Health, 3(1), 46-53.

Sodik, M. A., \& Setyani, A. T. (2018). Effect of Smoking For Teens Against Behavior and Social Interaction.

Lila, R. N. M., \& Sodik, M. A. (2019). Risk Factors Of Dental Career Events In Pres School Children Ra Al-Hakim Village Damage Subscription Kesamben Blitar District. Journal of Global Research in Public Health, 4(2), 105-112.

Sodik, M. A., Yudhana, A., \& Dwianggimawati, M. S. (2018). Nutritional status and anemia in islamic boarding school adolescent in Kediri City East Java Indonesia. Indonesian Journal of Nutritional Epidemiology and Reproductive, 1(3), 172-176.

Pratiwi, I. Y., \& Sodik, M. A. (2018). Dampak Positif dan Negatif Meminum Kopi.

Lopo, Y. M., \& Sodik, M. A. (2021). GERAKAN MASYARAKAT HIDUP SEHAT BEBAS MEROKOK.

Sodik, M. A., \& Widyastika, K. S. (2020). Analysis Completeness of Outpatient Medical Record Documents Completion Based on Motivation and Compliance with Basic Tasks and The Function of Officers. Journal of Global Research in Public Health, 5(1), 25-31. 